\title{
Orthid brachiopods from the Middle Ordovician of the Central Iberian Zone, Spain
}

Jaime Reyes-Abril, Enrique Villas, and Juan Carlos Gutiérrez-Marco

Acta Palaeontologica Polonica 55 (2), 2010: 285-308 doi: http://dx.doi.org/10.4202/app.2009.0032

The present study of a large collection of orthid brachiopods from Middle Ordovician (middle Darriwilian) strata of Spanish regions of the Central Iberian Zone of the Iberian Massif, as well as the type collection of Portuguese species from the same Zone, revealed the occurrence of five genera of the family Orthidae, two of them new, and to which most of the seven previously reported species of Orthis from the same areas can be assigned. Besides the two new genera and species Almadenorthis auriculata Reyes-Abril and Villas gen. et sp. nov., and Gutiorthis incurvata Reyes-Abril and Villas gen. et sp. nov., three further new species are erected: Paralenorthis estenaensis Reyes-Abril and Villas sp. nov., Paralenorthis lolae Reyes-Abril and Villas sp. nov., and Sivorthis calatravaensis Reyes-Abril and Villas sp. nov. Paralenorthis alata and Orthambonites sp. are also identified in the same beds. Orthis noctilio is ascribed to the genus Sivorthis, and the species Orthis lusitanica and Orthis miniensis are restricted to only their type specimens. Orthis duriensis is poorly described and illustrated, its type material missing, and actually it may belong to Sivorthis noctilio. These brachiopod taxa invaded the cold waters of the Afro-South European Gondwanan margin from lower latitudes, coincident with the mid Darriwilian transgression, as they belonged to a family that diversified in temperate and tropical seas during the early Mid Ordovician.

Key words: Brachiopoda, palaeobiogeography, Ordovician, Darriwilian, Mediterranean, Gondwana.

Jaime Reyes-Abril [jreyes@ula.ve ], Departamento de Geología General, Grupo TERRA, Facultad de Ingeniería, Universidad de Los Andes, Núcleo La Hechicera, Edificio Ingeniería, Piso 1, Ala Este, 5101. Mérida, Venezuela; Enrique Villas [villas@unizar.es ], Departamento de Ciencias de la Tierra, Facultad de Ciencias, Universidad de Zaragoza, C/ Pedro Cerbuna 10, 50009 Zaragoza, Spain; Juan Carlos Gutiérrez-Marco [jcgrapto@geo.ucm.es], Instituto de Geología Económica (CSIC-UCM), Facultad de Ciencias Geológicas, José Antonio Nováis 2, 28040 Madrid, Spain. 
This is an open-access article distributed under the terms of the Creative Commons

Attribution License (for details please see creativecommons.org), which permits unrestricted use, distribution, and reproduction in any medium, provided the original author and source are credited.

Forif Full text $(3,362.3 \mathrm{kB})$ 